\title{
ASSESSING THE BIOAVAILABILITY AND BIOACCESSIBILITY OF TOTAL ARSENIC AND ARSENIC SPECIES IN ENVIRONMENTAL SAMPLES
}

\author{
ISABEL PIZARRO*(1), DOMINGO ROMAN(1), MILAGROS GOMEZ ${ }^{(2)}$, M. ANTONIA PALACIOS ${ }^{(2)}$ \\ ${ }^{(1)}$ Facultad de Ciencias Básicas, Universidad de Antofagasta. 02800 Antofagasta (Chile) \\ ${ }^{(2)}$ Departamento de Química Analítica. Facultad de Ciencias Químicas. Universidad Complutense de Madrid
}

\begin{abstract}
Studies on the bioavailability of As, of impacted vegetables; and As bioaccesibility in the edible parts of carrots (daucus carota), beets (beta vulgaris) and quinoa (chenopodium) growing in polluted soils thought "in vitro" gastrointestinal process; the As speciation both in the edible parts of vegetables and in their gastrointestinal extracts have been performed. Elemental analysis and As speciation have been performed by ICP-MS and LC-ICP-MS, respectively. The Arsenic recovery after the in vitro gastrointestinal digestion was from 98,90 and $40 \%$ for carrots, beets and quinoa, respectively; with no significant transformation of original As species. These studies provide a clearer understanding of the impact that As and other contaminant elements may present in the population of this high polluted Chilean region.
\end{abstract}

Keywords: arsenic speciation, bioaccesibility, bioavailability, vegetables, gastrointestinal digestion.

\section{INTRODUCTION}

Since 1915, the Northern Chilean economy has been mainly supported by the exploitation of copper mining resources around the Atacama Desert. This mining activity produces heavy metals contamination of the water and aquifers of the Loa river basin and its tributaries such as the San Pedro, Salado and San Salvador rivers ${ }^{1,2}$.

Associated with copper and the other heavy metals from the mines, is arsenic, a very dangerous environmental element. This As is present in the enargita $\left(\mathrm{Cu}_{3} \mathrm{AsS}_{4}\right)$, one of the sulphur minerals of the mines. In this area, there are also copper mineral smelting plants and during the pyrometallurgical process, the As is released as $\mathrm{As}_{2} \mathrm{O}_{3}$ both in the gas phase and in fine particles ${ }^{3,4}$. It is believed that suspended dust particles and intake through the drinking water are the major sources of As exposure for living beings in the area. The concentration of As in the water of the Loa river's hydrographic basin is very different depending on place, and changes from no contamination in the Copiapó river (snow melting, concentration $<0.005 \mathrm{mg} \mathrm{L}^{-1}$ ) to extreme contamination in the San Salvador river $\left(2-2.5 \mathrm{mg} \mathrm{L}^{-1}\right)^{5}$.

Between 1958 to 1970 , the Antofagasta population had drinking water from the Loa river with a total As concentration of about $1000 \mu \mathrm{g} \mathrm{L}^{-1}$ (most probably in the form of $\mathrm{As}(\mathrm{V}))^{6}$. Successive water treatment has been decreasing the water concentration to an actual annual average of $50 \mu \mathrm{g} \mathrm{L}^{-1}$, but not in all places. This is far from the WHO's recommended amount of $10 \mu \mathrm{g}$ $\mathrm{L}^{-17}$. A study in 1992, showed the contamination of As in water and vegetables growing in the Antofagasta region ${ }^{8,9}$.

Therefore, natural geographic contamination, anthropological action, the zone's desert climate, and the exposure of vegetables, animal and human being communities to these extremes in environmental conditions, makes for a very delicate ecological equilibrium similar to what can be seen in other well-known parts of the world such as India, China, New Zealand ${ }^{10,11}$, etc. Cancerous and non-cancerous diseases associated with As contamination reach alarming levels in the Antofagasta region, as evidenced by the incidence of cardiovascular ${ }^{6,12}$ bronchial lung, bladder diseases and renal cancer ${ }^{13}$.

In addition to As, the characteristics of the mines themselves result in high concentrations of other heavy metals, which also have a high environmental and human impact. Indeed, the possible contaminating elements in the region $(\mathrm{Cu}, \mathrm{Cr}, \mathrm{Mn}, \mathrm{Hg}, \mathrm{Pb}$ and $\mathrm{Cd})$, are included on the list of priority toxic pollutants published by the World Health Organization (WHO) ${ }^{7}$ and the International Register of Potentially Toxic Chemicals (IRPTC) ${ }^{14}$.

The evaluation of food from the point of view of arsenic and trace element contribution to human diet requires knowledge not only of the total element content but also their absorption rates in the gastrointestinal tract. A way to quantify the absorbable fraction in trace element bioaccessibility is the "in vitro" simulation of digestion processes ${ }^{15}$.

It is also recognized that inorganic arsenic are probably the most dangerous forms of arsenic in food, being As (III) more toxic than As(V) ${ }^{16}$. The formation of As (III) from the As(V) species present in natural environmental conditions, obeys in some case to an a initial reduction before the methylation or other bigger species formation (arsenobetain, arsenosugar, etc.), in the detoxification mechanism that happens in microorganisms and also in more complex living beings $^{17-19}$. The methylation process first produces monomethylarsonic acid (MMA) and in a second step dimethylarsinic acid (DMA) both less toxic than inorganic forms because their interaction with tissues is weaker ${ }^{20}$.

There have been several reports of arsenic speciation in vegetables growing in natural or contaminated soils ${ }^{21}$. According Johnson et $\mathrm{a}^{22}$, rice contains the highest concentrations of inorganic arsenic species compared with other tested products. Broccoli, lettuce, potato, carrots, etc. can concentrate arsenic when the soil or the irrigation water contains As (V). In most of the vegetables, arsenic is taken up by plant roots via macro-nutrient transporters ${ }^{23,24}$. The coupling of the liquid chromatography (LC) to high sensitive detectors like ICP-MS ${ }^{25}$ and CV-AFS ${ }^{26}$, are the most frequent techniques for the detection and quantification of these inorganic and methylated As species at trace level after their smooth extraction from the samples ${ }^{27}$.

The objectives of this study have been centralized on the polluted Chiu Chiu region located Northern Chile that is about $10 \mathrm{Km}$ from Calama and 235 $\mathrm{Km}$ from Antofagasta city. The study performed which addressed the following points: i) The total As content in the edible parts of vegetables growing in the area where the indigenous population live. ii) The As species present in the edible parts of lyophilized vegetables. iii) The bioaccesibility of the total As in the edible parts of these vegetables under "in vitro" reproduction of gastrointestinal process and finally. iv) The possible transformation of original As species during the gastrointestinal process.

As far as we know, such global studies have not been performed yet in the area under investigation.

\section{MATERIALS AND METHODS}

\section{Instrumentation}

An inductively coupled plasma mass spectrometer, (HP-4500, Agilent Technologies, Analytical System, Tokio, Japan) operating under normal multielement tuning conditions was used for total arsenic and metals analysis. The main analytical parameters of the ICP-MS are the following (R.F. power: forward $1350 \mathrm{~W}$; reflected $2.2 \mathrm{~W}$; coolant argon flow rate $14 \mathrm{~L} \mathrm{~min}^{-1}$; auxiliary argon flow rate $0.9 \mathrm{~L} \mathrm{~min}^{-1}$; integration time $0.1 \mathrm{~s}$ per point, point per peak 3 ).

For As speciation the ICP-MS has been used as the detector system after LC species separation. The column effluent was directly introduced into a Meinhard-type concentration glass nebulizer and a double-pass Scott-type spray chamber with a surrounding water jacket maintained at $5^{\circ} \mathrm{C}$. Single ion monitoring at $\mathrm{m} / \mathrm{z} 75$ was used to collect the data. For chromatographic separation, a high-pressure pump (LDC Division, Riviera Beach, Florida, USA) was used as a sample delivery system. Samples of $100 \mu \mathrm{L}$ were introduced through a $0.45-\mu \mathrm{m}$ nylon syringe filter into the injection valve Rheodyne 9125 (USA). The connections between the HPLC and the ICP-MS were made of polytetrafluoroethylene tubing (i.d. $0.5 \mathrm{~mm}$ ). The HPLC column was a Hamilton PRP-X100 $(10 \mu \mathrm{m}, 250 \mathrm{~mm}$ x $4.1 \mathrm{~mm}$, Torrance, CA, USA) and Phenomenex precolumn $(25 \times 2.3 \mathrm{~mm} 12-20 \mu \mathrm{m})$.

All signal quantification was performed in the peak area mode. The 
peaks were integrated using either ICP-MS Plasma Lab software or Grams/32 software (Galactic Industries, Salem, NY, USA).

Sonopuls Ultrasonic Homogenizer (HD 2200 Bandelin Electronic Berlin, Germany) and a Selecta Vibromatic shaker were also used in the sample extraction process.

\section{Arsenic Species Solutions:}

The Standard of As (III) of $1000 \pm 2 \mathrm{mg} \mathrm{L}^{-1}$ was prepared in $\mathrm{HNO}_{3}(2 \%$, $\mathrm{m} / \mathrm{m}$ ), TraceCERT ${ }^{\mathrm{TM}}$ Ultra (Fluka, Sigma-Aldrich, Steinheim, Germany). The standard of As(V) $1000 \mathrm{mg} \mathrm{L}^{-1}$, was prepared in $\mathrm{HNO}_{3}(2 \% \mathrm{~m} / \mathrm{m})$, CertiPUR (Merck, Darmstadt, Germany). Dimethylarsinic acid (DMA) and methylarsonic acid (MMA) standard of $1000 \mathrm{mg} \mathrm{L}^{-1}$, were prepared from methyl disodium arseniate $\left(\mathrm{Na}_{2} \mathrm{CH}_{3} \mathrm{AsO}_{3}, 99 \%\right.$ Supelco, Bellefonte, PA, USA)) and cacodilic sodium trihydro $\left(\left(\mathrm{CH}_{3}\right)_{2} \mathrm{AsNa} 0.3 \mathrm{H}_{2} \mathrm{O}\right) 98 \%$, Fluka) TraceCERT ${ }^{\mathrm{TM}}$. These solutions were kept at $4^{\circ} \mathrm{C}$ in the dark. Working solutions were daily prepared and then diluted with water to the final concentration.

\section{Reagents}

All reagent were of analytical or reagent grade. $\mathrm{HNO}_{3} 60 \%$ (Scharlau), $\mathrm{HCl}(15 \%)$ (Scharlau), $\mathrm{HClO}$ (Scharlau), (acetic acid 99.8\% (Panreac), hydroxylamine hydrochoride $99 \%$ (Carlo Erba), hidrogen peroxide 33\% (Panreac), ammonium acetate 97\% (Scharlau), ammonium phosphate 98\% (Scharlau), alpha-amylase (Sigma Aldrich, Spain 11800 USP Units), pepsine (Sigma Aldrich, Spain, enzymatic activity 944 U/mg protein), pancreatin (Sigma Aldrich, Spain, activity equivalent to $4 \mathrm{x}$ US Pharmacopoeia specifications/mg pancreatin), lipase (Sigma Aldrich, Spain, 944 USP units), protease (Sigma Aldrich, Spain, 11800 USP units), bile extracts (glycine and taurine conjugates of hyodeoxycholic and other bile salts Sigma Aldrich, Spain). Deionized wate $(18.2 \mathrm{M} \Omega \mathrm{cm})$, obtained with a Milli-Q water system (Millipore, Inc., Spain) was used in the solutions preparation. Plastic and glassware was maintained in $10 \% \mathrm{HNO}_{3}$ for $24 \mathrm{~h}$ before use.

\section{Simulated gastrointestinal juices}

Salivary juice ( $\mathrm{pH} 6.8 \pm 0.1$ ) was prepared by dissolving $0.15 \mathrm{~g} \mathrm{NaH} P O$ $0.029 \mathrm{~g}$ amylase, $0.1 \mathrm{~g} \mathrm{KCl}$ and $0.1 \mathrm{~g} \mathrm{NaCl}$ and make up to $100 \mathrm{~mL}$ with water. Gastric juice (pH $1.8 \pm 0.1$ ) was prepared by dissolving $6.0 \mathrm{~g}$ of pepsin and 0.88 g sodium chloride (Sigma) in water, adjusting $\mathrm{pH} 1.8$ with $\mathrm{HCl}$ and making up to $100 \mathrm{~mL}$ with water. Intestinal juice was prepared just before use by mixing equal volumes of $\mathrm{A}$ and $\mathrm{B}$ solutions. (Solution A: $1.5 \mathrm{~g}$ pancreatin, $0.44 \mathrm{~g}$ sodium chloride, $30 \mathrm{mg}$ alpha-amylase and water up to $50 \mathrm{~mL}$. Solution B: $2 \mathrm{~g}$ bile salts, $0.44 \mathrm{~g}$ sodium chloride and water up to $50 \mathrm{~mL})^{28}$.

\section{Vegetable samples}

Chilean vegetables samples were collected from 3 different places of the Chiu Chiu Chilean area. About $10 \mathrm{Kg}$ of carrots (daucus carota), beets (beta vulgaris) and quinoa (chenopodium) were taken. For comparison about $2 \mathrm{Kg}$ of the same type of vegetables of Spanish origin were purchased. The samples were sent fresh from origin to laboratory and kept frozen under nitrogen atmosphere. The Figure 1 shows the places were Chilean carrots, beets and quinoa.

Certified Reference Materials (CRMs):

Rice flour (1568a NIST), white cabbage (BCR 679) and tomato leaves (NIST 1573a) were used as certified reference materials. The concentration of As and other heavy metals was determined on these CRMs following the same method as the one described below for the vegetables under study.

Sample treatment for determination of the total As content in lyophilized vegetable samples by ICP-MS analysis

The Carrots and beets were peeled with a plastic knife and the edible part was blended in a titanium blender until a homogeneous mash was achieved. A fraction of about $2 \mathrm{Kg}$ of flesh were lyophilized, bottled and maintained at $4^{\circ} \mathrm{C}$ until analysis. No other treatment apart from drying at $80^{\circ} \mathrm{C}$ and maintaining it at $4^{\circ} \mathrm{C}$ was performed on the quinoa.

For mineralization of vegetables about $0.5 \mathrm{~g}$, were digested in PTFE vessels adding $5 \mathrm{~mL}$ of concentrated $\mathrm{HNO}_{3}$ and $2 \mathrm{~mL}$ of $\mathrm{H}_{2} \mathrm{O}_{2}$ The mixture was maintained for about 4 hours in open air until vapor stoppage before microwave digestion under the following conditions: $600 \mathrm{~W}, 200{ }^{\circ} \mathrm{C}, 20 \mathrm{~min}$ and $150 \mathrm{psi}^{29,30}$.The digested samples were filtered, transferred to polyethylene containers diluted with $0.2 \mathrm{M} \mathrm{HCl}$ to appropriate volumes and stored at $4^{\circ} \mathrm{C}$ until analysis. The solid residue was discarded. Reagent blank did not show any significant contamination.

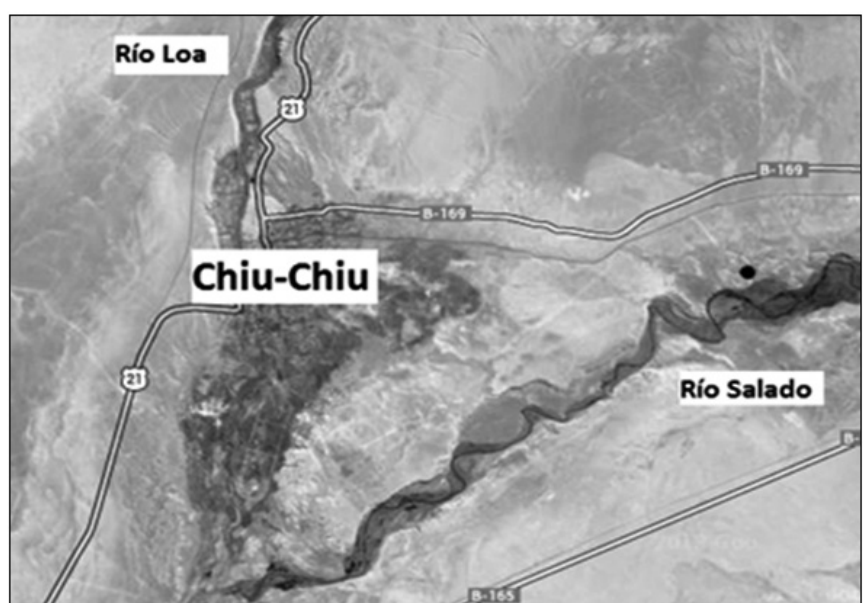

Figure 1: Chiu Chiu Region

The analytical characteristics of the method were the following: detection limits (DL) in $\mu \mathrm{g} \mathrm{Kg}^{-1}, 5.0$. Relative standard deviation (RSD), $\%$. Method validation was performed by triplicate with the above mentioned CRMs.

"In vitro" gastrointestinal digestion of vegetables for arsenic bioaccesibility by ICP-MS:

Samples were digested following a simulated digestion process with three steps $^{28}$.

Salivary digestion:

About $1.0 \mathrm{~g}$ of lyophilized sample was placed in a $25 \mathrm{~mL}$ erlenmeyer with $5 \mathrm{~mL}$ of salivary juice and $2 \mathrm{~mL}$ water and shacked in a vibromatic Pselecta ( $508 \mathrm{U} / \mathrm{min}$ ) for $5 \mathrm{~min}$ for degassing. The $\mathrm{mix}$ was heated for $5 \mathrm{~min}$ in a water bath $\left(37-39^{\circ} \mathrm{C}\right)$, shacked $5 \mathrm{~min}$, heated again for $5 \mathrm{~min}$ and centrifuged at 5000 rpm during 20 min to separate salivary and solid phases.

Gastric digestion:

$10 \mathrm{~mL}$ of the prepared gastric juice, was added to the solid fraction after salivary digestion, heated for $1 \mathrm{~h}$ in a water bath, shacked for $30 \mathrm{~min}$ in the vibromatic Pselecta (508 U/min), adjusting the $\mathrm{pH}$ to 1.8 with $\mathrm{HCl}(15 \%)$, and heated $3 \mathrm{~h}$ more at $36-39^{\circ} \mathrm{C}$. The mixture was centrifuged at $5000 \mathrm{rpm}$ for 20 min to separate the soluble and solid fractions.

Intestinal digestion:

$10 \mathrm{~mL}$ of the prepared intestinal juice was added to the solid fraction obtained before and the procedure was repeated as in the gastric digestion. The remained solid extract was discarded. ${ }^{15}$

The three liquid extracts after digestion were mineralized in a microwave oven and appropriately diluted and analyzed by ICP-MS.

\section{Extraction procedures for As(III), As(V), MMA and DMA speciation} by $\mathrm{LC}$-ICP-MS in vegetables

Procedure1: Methanol: water extraction. To $0.5 \mathrm{~g}$ of the fresh homogeneous mesh of edible part of vegetables, was added $5 \mathrm{~mL}$ of methanol: water (1:1) solution. The mixture was heated for $30 \mathrm{~min}$, at $55^{\circ} \mathrm{C}$, focalized ultrasonic probe for $5 \mathrm{~min}$ and centrifuged at $5000 \mathrm{rpm}$ for $20 \mathrm{~min}$ at ambient temperature. The procedure was repeated in the solid fraction. The two liquid extracts were mixed and evaporated to a final volume of $2 \mathrm{~mL}$.

Procedure 2: Enzymatic extraction. To $0.3 \mathrm{~g}$ of the fresh homogeneous mesh of edible part of vegetables, was added, $10 \mathrm{mg}$ alpha-amylase and $3 \mathrm{~mL}$ water. The mixture was focalized ultrasonic probe for $60 \mathrm{~s}$ in a bath ice and $30 \%$ power. After that, was added $30 \mathrm{mg}$ protease, focalized ultrasonic probe for $120 \mathrm{~s}$ at $30 \%$ power and centrifuged for $10 \mathrm{~min}$ at $4000 \mathrm{rpm}$. The solution was made up to $2 \mathrm{~mL}$ for analysis ${ }^{31}$.

The two procedures were performed in triplicate. Table 1 shows the chromatographic conditions for As species separation. 
Table 1: Chromatographic conditions for As species separation

\begin{tabular}{|c|c|c|}
\hline \multirow{3}{*}{$\begin{array}{c}\text { PROCEDURE } \\
1\end{array}$} & $\begin{array}{c}\text { MoBile } \\
\text { PHASE }\end{array}$ & $\left(\mathrm{NH}_{4}\right) \mathrm{H}_{2} \mathrm{PO}_{4}(\mathrm{~A}: 5 \mathrm{MM} ; \mathrm{B}: 25 \mathrm{MM}), \mathrm{pH} 6$ \\
\hline & GRADIENT & \multirow{2}{*}{$\begin{array}{l}\text { 0-15 MIN (A: } 100-0 \text { y B: } 0-100) \\
15-25 \text { MIN (A: } 0-100 \text { AND B: } 100-0) \\
\text { FLOW RATE: } 1 \text { ML X MIN. } \\
\text { RECONDITIONS: } 25-30 \text { MIN (A: } 100, \text { B:0) }\end{array}$} \\
\hline & & \\
\hline \multirow{3}{*}{$\begin{array}{c}\text { PROCEDURE } \\
2\end{array}$} & MOBILE PHASE & $\left(\mathrm{NH}_{4}\right) \mathrm{H}_{2} \mathrm{PO}_{4}(10 \mathrm{MM})$, PH 6 \\
\hline & \multirow{2}{*}{ ISOCRATIC } & FLOW RATE 1 ML X MIN. \\
\hline & & RECONDITIONS: 25 MIN (A:100) \\
\hline
\end{tabular}

\section{Statistical analysis}

All experiments were performed at least in triplicate. Differences were considered significant when $\mathrm{p}<0.05$ following the t Student's test ${ }^{32}$.

\section{RESULTS AND DISCUSSION}

Determination of total arsenic content and bioaccesibility in carrots (Daucus carota) beets (Beta vulgaris) and quinoa (Chenopodium quinoa)

Table 2 shows the total concentration of As in the lyophilized flesh of carrots and beets and the fresh quinoa growing in contaminated soils; the concentration of the same vegetables bought in the Spanish market, and the As concentration rate between Chilean and Spanish samples. The concentrations of As tested in the Spanish samples fall within those levels reported for uncontaminated vegetables ${ }^{33}$.

Table 2: Total As content in Chilean and Spanish lyophilized vegetables. Results expressed as mean $\pm \mathrm{SD}(\mathrm{mg} \mathrm{kg}-1)$ for $\mathrm{n}=3$ determinations.

\begin{tabular}{|c|c|c|}
\hline \multicolumn{2}{|c|}{ Vegetables } & As \\
\hline \multirow[t]{2}{*}{ Carrots } & $\begin{array}{c}\text { Flesh-C } C^{(1)} \\
\text { Flesh-C }^{(2)} \\
\text { Flesh-S } \\
\text { Factor }\end{array}$ & $\begin{array}{c}0,52 \pm 0.04 \\
0,54 \pm 0,06 \\
0,02 \pm 0,01 \\
\mathbf{2 4}\end{array}$ \\
\hline & $\begin{array}{c}\text { Peel-C }^{(1)} \\
\text { Peel -S } \\
\text { Factor }\end{array}$ & $\begin{array}{c}1,62 \pm 0,02 \\
0,15 \pm 0,01 \\
\mathbf{1 1}\end{array}$ \\
\hline \multirow{2}{*}{ Beets } & $\begin{array}{c}\text { Flesh-C }^{(1)} \\
\text { Flesh-C } \\
\text { Flesh-S } \\
\text { Factor }\end{array}$ & $\begin{array}{c}0,62 \pm 0.05 \\
0,64 \pm 0,07 \\
0,02 \pm 0,00 \\
\mathbf{2 6}\end{array}$ \\
\hline & $\begin{array}{l}\text { Peel-C }^{(1)} \\
\text { Peel-S } \\
\text { Factor }\end{array}$ & $\begin{array}{c}3,20 \pm 0,06 \\
0,22 \pm 0,01 \\
\mathbf{1 4}\end{array}$ \\
\hline \multicolumn{2}{|c|}{$\begin{array}{c}\text { Quinoa }-\mathrm{C}^{(1)} \\
\text { Quinoa-C } \mathrm{C}^{(2)} \\
\text { Quinoa -S } \\
\text { Factor }\end{array}$} & $\begin{array}{c}0,20 \pm 0,02 \\
0,21 \pm 0,04 \\
0.01 \pm 0,01 \\
\mathbf{2 0}\end{array}$ \\
\hline
\end{tabular}

C: Chilean; S: Spanish. Factor: Metal concentration in Chilean /Spanish samples. ${ }^{(1)}$

Table 3: shows results for the White Cabbage, Rice Flour 1568 and Tomato Leaves (NIST 1573a) CRMs, used to validate the total As determination.

\begin{tabular}{|c|c|c|c|}
\hline & $\begin{array}{l}\text { Certified value } \\
\left(\mathrm{mg} \mathrm{K}^{-1}\right)\end{array}$ & $\begin{array}{r}\text { Experimental } \\
\text { value }\left(\mathrm{mg} \mathrm{K}^{-1}\right)\end{array}$ & $\begin{array}{c}\% \\
\text { Error }\end{array}$ \\
\hline \multirow[t]{2}{*}{$\begin{array}{c}\text { White Cabbage } \\
\text { BCR } 679^{(1)}\end{array}$} & $7,0 \pm 3,8$ & $8.5 \pm 2,0$ & 21 \\
\hline & $\begin{array}{c}\text { Certified value } \\
\left(\mathrm{mg} \mathrm{K}^{-l}\right)\end{array}$ & $\begin{array}{l}\text { Experimental } \\
\text { value }\left(\mathrm{mg} \mathrm{K}^{-1}\right)\end{array}$ & \\
\hline Rice Flour $1568^{a(1)}$ & $0,29 \pm 0,03$ & $0,29 \pm 0,04$ & 2 \\
\hline $\begin{array}{l}\text { Tomato Leaves } \\
(\text { NIST } 1573 a)^{(1)}\end{array}$ & $0.112 \pm 0.004$ & $0,110 \pm 0,006$ & 2 \\
\hline
\end{tabular}

Table 3: Quality control and traceability of the total As concentrations, using standard reference materials (SRM).

Analysis performed by ICPMS ${ }^{(1)}$

Table 4, shows the total As content and the As concentration in the different extracts of the "in vitro" gastrointestinal digestion process. In order to check the possible interference of chloride in the ${ }^{75} \mathrm{As}$ signal due to the formation of ${ }^{40} \mathrm{Ar}^{35} \mathrm{Cl}^{+}$during ICP-MS analyses, the signal at $\mathrm{m} / \mathrm{z} 75$ of salivary, gastric and intestinal juices were registered. It was observed that the signal intensity for the three extracts was negligible and did not differ from that of a blank solution, which indicates that the procedure is free of interference by chloride.

The comparison of the total As content and total extracted As shows that practically the whole As is bioaccesible from carrots and beets $(98 \%$ and $90 \%$ respectively). However, for quinoa, only about $40 \%$ of As is bioaccesible. Fresh carrots and beets have an water content of about $85 \%$, while in quinoa it is only about $10 \%$. It has been reported that the average consumption per inhabitant of quinoa in the Andean countries is about $1.15-2.35 \mathrm{Kg}$ per year ${ }^{34}$ and about 2-6 Kg per year for carrots and beets. Considering: the maximum intake of $2.5 \mathrm{Kg}$ per year of quinoa and of $6 \mathrm{Kg}$ per year of carrots and beets; the As concentration in the lyophilized vegetables; the water content and the As bioaccesibility, the calculated accessible doses of As expressed as $\mu \mathrm{g}$ As per year, is about 470 for carrots, 550 for beets and 180 for quinoa. Therefore, quinoa seems to be the vegetable with the lower toxicological risk from the bioaccesible point of view.

Table 4: Bioaccesibility of As in the digestion process of Chilean samples by ICP-MS. Results expressed in lyophilized vegetables as mean $\pm \mathrm{SD}$ ( $\mu \mathrm{g}$ $\mathrm{kg}-1$ ) for $\mathrm{n}=3$ determinations.

\begin{tabular}{|c|c|c|c|c|}
\hline \multicolumn{2}{|c|}{} & Carrots & Beets & Quinoa \\
\hline \multirow{2}{*}{$\begin{array}{c}\text { Extracted As } \\
\left(\mu \mathrm{g} \mathrm{Kg}^{-1}\right)\end{array}$} & Salivary & $313 \pm 18$ & $289 \pm 28$ & $34 \pm 4$ \\
\cline { 2 - 5 } & Gastric & $135 \pm 12$ & $186 \pm 21$ & $31 \pm 4$ \\
\cline { 2 - 5 } & Intestinal & $65 \pm 9$ & $84 \pm 10$ & $13 \pm 6$ \\
\hline \multicolumn{2}{|c|}{ Total extracted As $\left(\mu \mathrm{g} \mathrm{K}^{-1}\right)$} & $513 \pm 45$ & $559 \pm 38$ & $78 \pm 15$ \\
\hline \multicolumn{2}{|c|}{ Total As $\left(\mu \mathrm{g} \mathrm{K}^{-1}\right)$} & $520 \pm 41$ & $616 \pm 57$ & $196 \pm 24$ \\
\hline \multicolumn{2}{|c|}{ Recovery $(\%)$} & $98 \pm 3$ & $90 \pm 4$ & $40 \pm 4$ \\
\hline
\end{tabular}

As speciation in carrots, beets and quinoa:

In the speciation studies, an important step is the extraction efficiency of the species present in the sample. Table 5 shows the total As concentration in the vegetables under study referred to fresh flesh and the extraction efficiency in the methanol water 1:1 extract and in the enzymatic extracts, by ICP-MS procedures. As can be seen, methanolic extraction is appropriate for extraction of the total As species in carrots and quinoa, but not for beets, in which the enzymatic extraction is necessary.

Table 5: Methanolic and enzymatic extraction efficiency for total As by ICP-MS in carrots, beets and quinoa, and As species contribution (\%) to total As content in both extracts. $n=3$.

\begin{tabular}{|c|c|c|}
\hline Vegetables & $\begin{array}{c}\text { Methanolic Extraction } \\
\text { Efficiency }(\%)\end{array}$ & Enzymatic Extraction \\
& Efficiency $(\%)$ \\
\hline \multirow{3}{*}{ Carrots } & Total As: $97 \pm 5$ & Total As: $12 \pm 5$ \\
& As(III): $45 \pm 7$ & As(III): <DL \\
& As(V): $43 \pm 5$ & As(V): <DL \\
\hline \multirow{3}{*}{ Beets } & Total As: $10 \pm 2$ & Total As: $95 \pm 9$ \\
& As(III): $<$ DL & As(V): $20 \pm 5$ \\
& As(V): $<$ DL & Unknown: $70 \pm 3$ \\
\hline \multirow{3}{*}{ Quinoa } & Total As: $99 \pm 6$ & Total As: $7.4 \pm 0.9$ \\
& As(III): $15 \pm 4$ & As(III): $<$ DL \\
& As(V): $82 \pm 9$ & As(V): $<$ DL \\
\hline
\end{tabular}

Table 5 shows the species As(III), DMA, MMA and As(V) detected in the methanolic (for carrot and quinoa) and enzymatic (for beet) extracts by LC-ICP-MS. Extracts were appropriately diluted in each case. The species for beets, were characterized by spiking the sample with $5 \mu \mathrm{g} \mathrm{L}^{-1}$ of As(III) and $\mathrm{As}(\mathrm{V})$. For carrots, only As(III) and As(V) are present. Relative peaks quantification, show about a $50 \%$ distribution between the two inorganic As. 
These results agree with results obtained in previous work ${ }^{27}$. For quinoa, $90 \%$ of the As is present as $\mathrm{As}(\mathrm{V})$, been the $\mathrm{As}(\mathrm{V})$ concentration of $\mathrm{As}(\mathrm{III})$ about $10 \%$. No other species are found in the methanolic fraction. Beets show a different behavior. As species present in this vegetable is only slightly extracted in methanol - water but almost $100 \%$ in the enzymatic hydrolysis.

As speciation in the salivary, gastric and intestinal extracts for carrots and quinoa.

In order to know if the digestion process could change the original species present in the food, changes in their bioaccesibility, a speciation analysis has been performed in the salivary, gastric and intestinal juice of carrots and quinoa.

The analysis was performed by LC-ICPMS under the same conditions than performed in original samples. Table 6 shows the results obtained for carrots. Similar results were obtained in quinoa sample. The percentages are given respect to the whole content in the corresponding extract.

Table 6: Comparison of the As species distribution in the methanolic extract for carrots and quinoa and enzymatic extract for beets and the As species distribution in the whole gastrointestinal extract with respect to the total As extracted.

\begin{tabular}{|c|c|c|}
\hline Vegetables & $\begin{array}{c}\text { Species distribution\% } \\
\text { Methanolic or enzymatic } \\
\text { extract }\end{array}$ & $\begin{array}{c}\text { Whole Gastrointestinal } \\
\text { extract }\end{array}$ \\
\hline \multirow{2}{*}{ Carrots } & As(III): $45 \pm 7$ & As(III): $50 \pm 10$ \\
As(V): $43 \pm 5$ & As(V): $36 \pm 15$ \\
\hline \multirow{3}{*}{ Beets } & As(III): $<$ DL & As(III): $<$ DL \\
& As(V): $20 \pm 5$ & As(V): $33 \pm 7$ \\
\hline \multirow{2}{*}{ Quinoa } & Unknown: $70 \pm 3$ & Unknown: $70 \pm 12$ \\
& As(III): $15 \pm 4$ & As(III): $<$ DL \\
& As(V): $82 \pm 9$ & As(V): $75 \pm 7$ \\
\hline
\end{tabular}

When vegetables grow in contaminated soils, the bioavailable part of the elements present in the soil can pass to the vegetable through intake mechanisms in which the microorganisms present in the soil are frequently involved, and the proper structure of the vegetal ${ }^{35,36}$. The Spanish samples are in the level reported for plants growing in non-contaminated soils ${ }^{37,38}$. It is relevant that only $\mathrm{As}(\mathrm{III})$ and $\mathrm{As}(\mathrm{V})$ are present in carrots and quinoa, this is not the case of beets, were $\mathrm{As}(\mathrm{V})$ and mainly un unknown As species are presented (Table 6). Sacarose is the sugar extracted from the beets; therefore an As-sacarose or derivatives could be the unknown species. Considering that inorganic species are the most toxic ones, beet could be the vegetable with the lower concern ${ }^{39}$. It is known than the terrestrial plants in general have very low efficient mechanisms of biometilation ${ }^{40}$. Probably also the drastic conditions of these soils from the environmental point of view make it difficult for the microorganisms present in the soil, to develop biomethylation mechanisms giving methylated species able to be absorbed through the roots of these vegetables as proposed by $\mathrm{Ye}$ and col. $^{41}$

It is well known than the main contribution of contaminant (and also nutrient) elements to living beings arise from consumption of food and water This happens also for arsenic. As can be seen, the "in vitro" digestion process carried out in the studied vegetables liberates the whole As from carrots and beets (Table 4), and therefore this vegetables intake could be dangerous if concentration in the samples is high enough to be a toxic doses. Quinoa behavior is different and only about $40 \%$ of As is liberated. For the three vegetables, about $50-60 \%$ of the total concentration extracted is released in the salivary juice. It is important to highlight that for beets and carrots, results about total concentration of As, and the sum of the bioaccesibility fractions of As under the digestion process are very similar. However, the quinoa behavior is different and only is recovered after the whole digestion process about a $40 \%$. Fresh carrots and beets have a water content of about $85 \%$, while quinoa is only of about $10 \%$. Concentration of As referred to fresh vegetables shows that quinoa pre-concentrate about 3 times more As that the others, but its bioaccesibility is about half of the carrots and beets, therefore not mayor concern than carrots and beets can be expected for this vegetable considering a similar intake.

Knowledge of oral bioaccesibility of a contaminant is useful for estimating potential human health risks. However, it is even more important to know the species under which the contaminant is liberate to bloodstream. Table 6 shows that not significant transformation of As species after "in vitro" gastrointestinal digestion occurs in comparison to the original species. As(III) is extracted mainly in the two first extracts and As(V) mainly in the last for quinoa and carrots. Previous studies of Calatayud $\mathrm{M}$ et al. ${ }^{42}$ show the transformation of $\mathrm{As}(\mathrm{V})$ to $\mathrm{As}(\mathrm{III})$ after gastrointestinal digest when other vegetables, differen to that of this study, are contaminated with As(V) after soaking or boiling.

Although some others studies can be found about the determination of As in soils and vegetable in the II Chilean Region, the diversity of the places where different levels of contamination can be found, the different sources of contamination and the different As water concentration depending on the river and the section, made difficult to compare our results with the content in the Chilean bibliography. A precedent work performed by us ten years ago, showed a higher concentration of As in carrots growing in the same area ${ }^{43}$. The studies of Ferreccio C. et al.$^{44}$ reports concentrations of As slightly higher than reported in this study for vegetables in the region.

\section{CONCLUSION}

The "in vitro" digestion process has shown that As species and As bioaccesibility in the carrots, beets and quinoa growing in the same soil contaminated by the element differ between vegetables. Inorganic As (III) and $\mathrm{As}(\mathrm{V})$ are present in carrots and quinoa. Unknown species are the main components of As in beets, probably arsenosugars derivatives. Bioaccesibility of As in carrots and beets was almost, $100 \%$, while for quinoa was about $40 \%$. Considering the maximum intake of $2.5 \mathrm{Kg}$ per year of quinoa and of $6 \mathrm{Kg}$ per year of carrots and beets; the As concentration in the lyophilized vegetables; the water content of $10 \%$ in the quinoa and $85 \%$ en beets and carrots, the As bioaccesibility obtained and the main As species present in the vegetables, the accessible doses of As is about $470 \mu \mathrm{g}$ per year for carrots, about $550 \mu \mathrm{g}$ per year for beets and about $180 \mu \mathrm{g}$ per year for quinoa. Therefore, quinoa seems to be the vegetable with lower toxicological implication. The As speciation in the salivary, gastric and intestinal extracts of carrots showed that no significant transformation of As species after "in vitro" gastrointestinal digestion occurs. $\mathrm{As}(\mathrm{III})$ is mainly found in the salivary and gastric extracts and As(V) mainly in intestinal extract for the tested vegetables.

More research is necessary to determine the species present in the beets where identification is limited by both the availability of standards and the complexity of the matrix.

\section{REFERENCES}

1.- G. Lagos, E. Blanco, Resources Policy. 35, 265, (2010).

2.- M.P. Bugueño, S.E. Acevedo, C.A. Bonilla, G.E. Pizarro, P.A. Pasten, Sci Total Environ. 466, 387, (2014).

3.- E. Sträter, A. Westbeld, O. Klemm, Environ Sci Pollut Res. 17, 1563, (2010)

4.- A. Soriano, S. Pallarés, F. Pardo, A.B. Vicente, T. Sanfeliu, J. Bech, Journal of Geochemical Exploration. 113, 36, (2012).

5.- J. Pizarro, P.M. Vergara, J.A. Rodríguez, A.M. Valenzuela, J. Hazard Mater. 181,747, (2010).

6.- C.M. Steinmaus, C. Ferreccio, J. Acevedo Romo, Y. Yuan, S. Cortés, G. Marshall, E. M. Lee, J.R. Balmes, J. Liaw, Cancer Epidemiol Biomarkers Prev. 22, 623, (2013)

7.- WHO, Guideline for Drinking Water Quality.1,2. Geneva: World Health Organization, 1992, pp 41

8.- H.C. Flynn, V. Mc Mahon, G. Chong Díaz, C.S. Demergasso, P. Corbisier, A.A. Meharg, G.I. Paton, Sci Total Environ. 286, 51, (2002).

9.- L. Romero, H. Alonso, P. Campano, L. Fanfani, R. Cidu, C. Dadea, T. Keegan, I. Thornton, M. Farago, Applied Geochemistry 18, 1399, (2003).

10.- D.A. Ahsan, T.A. Del Valls, Int. J. Environ. Res. 5, 627, (2011).

11.- Z. Huang, X. Pan, P. Wu, J. Han, Q. Chen, Food Control. 36, 248, (2014).

12.- D.A. Roman, I. Pizarro, L. Rivera, C. Cámara, M.A. Palacios, M. Gómez, C. Solar, Human and Experimental Toxicology 30, 1139, (2011).

13.- C. Ferreccio, A. Smith, V. Duran, T. Barlaro, H. Benitez, R. Valdés, J.J. Aguirre, L.E. Moore, J. Acevedo, M.I. Vásquez, L. Pérez, Y. Yuan, J. Liaw, K. P. Cantor, C. Steinmaus, Am J Epidemiol. 178, 813, (2013).

14.- M.N.V.Prasad, Trace Elements as Contaminants and Nutrients. Consequences in Ecosystem and Human Health. United States of America, Canada. Wiley (2008).

15.- S.J. Hur, B.O. Lim, E.A. Decker, D.J. McClements, Food Chemistry 125 , $1,(2011)$.

16.- M.M. Moriarty, I. Koch, K.J. Reimer, Arch Environ Contam Toxicol. 62, $529,(2012)$.

17.- K.A. Francesconi, Pure \& Applied Chemistry 82, 373, (2010).

18.- W.R. Cullen, Chem. Res. Toxicol. 27,457, (2014). 
19.- X.X. Yin, Y.Y. Zhang, J. Yang, Y.G. Zhu, Environmental Pollution 159, 837, (2011).

20.- M. Hamdi, M. Yoshinaga, C. Packianathan, J. Kin, J. Mc. Hallauer, J.R. Dermott, H. C. Yang, K. J. Tsai, Z. Liu, Toxicol Appl Pharmacol. 262, $185,(2012)$

21.- A. Pel, A. Márquez, J. Fermín, R. Rubio, M. Barbero, S. Stegen, F. Queirolo, P. Díaz-Palma, Chemosphere 90, 556, (2013).

22.- M.O Johnson, H.H.P Cohly, R.D. Isokpehi, O. R. Awofolu, Int. J. Environ. Res. Public Health 7, 1970, (2010).

23.- F.J. Zhao, S.P. McGrath, A.A. Meharg, Annu. Rev.Plant Biol. 61,535, (2010).

24.- Z. Wu, H. Ren, S.P. McGrath, P. Wu, F.J. Zhao, Plant Physiology 157, 498, (2011).

25.- E. do N. da Silva, F. Aureli, M. D”Amato, A. Raggi, S. Cadore, F. Cubadda, J. Agric. Food Chem. 65, 3031, (2017)

26.- L. Yuting, Y. Danyi, X. Song, S. Wang, M. Song, T. Hang. Journal of Trace Elements in Medicine and Biology 44, 17, (2017).

27.- I. Pizarro, M. Gómez, C. Cámara, M.A. Palacios, Analytica Chimica Acta. 495, 85, (2003).

28.- R.B. Khouzam, P. Pohl, R. Lobinski, Talanta 86, 425, (2011).

29.- C. Esen, A. Balci, J. Biol.\& Chem. 36, 123, (2008).

30.- S.M. Enamorado, J.M. Abril, Analytical Chemistry 2013, 1, (2013).

31.- J.L. Guzman, L. Hinojosa, G.M. Mizanur, H.M. Skip, J. Agric. Food Chem. 57,3005,(2009).

32.- W.R. Ott, Environmental statistics and data analysis. Boca Raton, New
York: CRC Lewis Publisher, (1995).

33.- S.W. Ramalli, P.I. Haris, C.F. Harrington, M.A. Ayub, Science of the Total Environment 337, 23, (2005).

34.- FAO-ALADI Tendencias y perspectivas del Comercio Internacional de Quinoa (Asociación latinoamericana ALADI y Organización de la Naciones Unidas para la alimentación y la Agricultura (FAO). Diciembre 2013; www.fao.org/31a-i35835.pdf

35.- M. Intawongse, J.R. Dean, Environmental Pollution 152, 60, (2008).

36.- T. T. Xiong, T. Leveque, A. Austruy, S. Goix, E. Schreck, V. Dappe, S. Sobanska, Y. Foucault, C. Dumat, Environ Geochem Health DOI: 10.1007/s10653-014-9607-6, (2014).

37.- M.N. Matos - Reyes, M.L. Cervera, R.C. Campos, M. De la Guardia, Food Chemistry $122,188,(2010)$

38.- J.A. Rodríguez Martín, J.J. Ramos - Miras, R. Boluda, C. Gil, Geoderma 200,180, (2013)

39.- J. Feldmann, E.M. Krupp, Anal Bioanal Chem 399, 1735, (2011).

40.- G. Norton, C. Deacon, A. Mestrot, J. Feldmann, P. Jenkins, C. Baskaran, A. Meharg, Environ Sci Technol. 47, 6164, (2013).

41.- J. Ye, C. Rensing, B.P. Rosen, Y.Z. Guan, Trends in Plant Science, 3, 155, (2012).

42.- M. Calatayud, E. Bralatei, J. Feldmann, V. Devesa, D. Vélez, J. Agric Food Chem. 61, 12164, (2013).

43.- I. Pizarro, M. Milagros, M.A. Palacios, C. Cámara, Intern. J. Environ. Anal. Chem. 83,879, (2003).

44.- C. Ferreccio, A. M. Sancha, J Health Popul Nutr 24, 164, (2006). 